\title{
Correction: Tranilast enhances the anti-tumor effects of tamoxifen on human breast cancer cells in vitro
}

\author{
Sara Darakhshan ${ }^{1}$, Ali Bidmeshki Pour ${ }^{1 *}$ and Ali Ghanbari ${ }^{2^{*}}$
}

\section{Correction}

After publication of this work [1], we noted that we inadvertently failed to include the complete list of all coauthors. The full list of authors has now been added and authors' contributions have been updated.

\section{Competing interests}

The authors declare that they have no competing interests.

\section{Authors' contributions}

$\mathrm{SD}$ performed the experiments and drafted the manuscript; AGH designed research and performed the statistical analysis; $A B$ designed research. All authors read and approved the final draft of the manuscript.

Received: 2 December 2013 Accepted: 2 December 2013

Published: 6 December 2013

\section{Reference}

1. Darakhshan, Ghanbari: Tranilast enhances the anti-tumor effects of tamoxifen on human breast cancer cells in vitro. J Biomed Sci 2013, 20:76.

\footnotetext{
* Correspondence: abidmeshki@razi.ac.ir; aghanbari@kums.ac.ir ${ }^{1}$ Department of Biology, Faculty of Science, Razi University, Kermanshah, Iran ${ }^{2}$ Fertility and Infertility Research Center, Kermanshah University of Medical Sciences, Kermanshah, Iran
}

Submit your next manuscript to BioMed Central and take full advantage of:

- Convenient online submission

- Thorough peer review

- No space constraints or color figure charges

- Immediate publication on acceptance

- Inclusion in PubMed, CAS, Scopus and Google Scholar

- Research which is freely available for redistribution

Submit your manuscript at www.biomedcentral.com/submit 